\title{
Assessment of the accuracy of physiological blood indicators for the evaluation of stress, health status and welfare in Siberian sturgeon (Acipenser baerii) subject to chronic heat stress and dietary supplementation
}

\author{
Rémy Simide • Simone Richard • Nathalie Prévot-D’Alvise $\cdot$ Thomas Miard • \\ Sandrine Gaillard
}

Received: 18 November 2015/Accepted: 29 February 2016/Published online: 14 March 2016

(c) The Author(s) 2016. This article is published with open access at Springerlink.com

\begin{abstract}
There is growing interest in the evaluation of stress, health and welfare of farm-raised fish. However, there is no scientific consensus about the methodology that is used to assess them. Sturgeon aquaculture is a recent industry with increasing interest in the production of caviar, which is characterized by high turnover and costs. To improve aquaculture efficiency, this study was conducted on routine blood samples, taken from Siberian sturgeon (Acipenser baerii), to test the robustness of using only physiological indicators to assess heat stress, health, and welfare. Sampling was performed after 1 month of prebiotic dietary supplementation followed by 4 weeks of sublethal heat stress. Data interpretation was achieved with a multivariate statistical tool. The expression of heat shock proteins (HSP) was assessed for the first time in sturgeon erythrocytes. $H s p 70$ and $h s p 90$ expression was triggered by both stress and dietary supplementation. Indicators of non-specific immunity were modified mainly by stress. Complement activity increases with stress while lysozyme activity decreases, but to a lesser extent in supplemented fish. The antioxidant capacity increases with stress while oxidant metabolites decrease and overall oxidative stress was lower for fish that received dietary supplementation. The positive impact of dietary supplementation on health status was observable after a stress challenge. A principal component analysis was used to combine all the measured parameters and to observe patterns in physiological fish status. The four experimental groups of fish were clearly discriminated with this statistical tool. Physiological indicators from blood samples may enable heat stress, health, and welfare to be assessed in Siberian sturgeon.
\end{abstract}

Keywords Fish $\cdot$ Welfare $\cdot$ Heat stress challenge $\cdot$ Blood sample $\cdot$ Heat shock protein (HSP) $\cdot$ Immunity $\cdot$ Oxidative stress $\cdot$ Multivariate analysis

\section{Introduction}

Sturgeon aquaculture is a recent industry, which has seen exponential growth in both production (between 2003 and 2008 production has almost doubled) and turnover (a tenfold increases between 2000 and 2012)

R. Simide $(\bowtie) \cdot$ S. Richard $\cdot$ N. Prévot-D’Alvise $\cdot$ S. Gaillard

Laboratoire PROTEE, Équipe de Biologie Moléculaire Marine, Université de Toulon, 6058483041 Toulon Cedex 9, France

e-mail: remy.simide@univ-tln.fr

T. Miard

Institut Océanographique Paul Ricard, Iles des Embiez, Le Brusc, 83140 Six Fours les Plages, France

S. Gaillard

Plateforme Technologique BioTechServices, Université de Toulon, 6058483041 Toulon Cedex 9, France 
(based on Food and Agricultural Organization statistics 2013). It is a dynamic and competitive industry and numerous improvements could be made to increase productivity and farm efficiency. The incentives of caviar production are very attractive with a proportion of sturgeon aquaculture dedicated to this activity. This requires the costly farming of females for several years until they reach sexual maturity. During this long process, environmental conditions and management techniques greatly influence both fish physiology and phenotype, as well as caviar quality (Lu and Rasco 2014). In addition, the age at which oocytes reach maturation is highly variable between farming facilities. Thus, as far as caviar production is concerned, the survival rate of valuable females, oocyte maturation time, and the quality and quantity of caviar produced by each female, are all vitally important parameters. It would thus seem to be the case that productivity in sturgeon farming is directly linked to fish welfare and health status. Therefore, fish monitoring during the farming process could be an issue of major importance.

Concerns about the welfare of farmed animals is a recent consideration. Currently there is no unified definition for fish welfare nor any consensus on how this should be assessed (Ashley 2007; Huntingford and Kadri 2009). However, there does exist several methodologies for the assessment of fish welfare in aquaculture. These encompass health status, physical, physiological, or behavioral parameters of fish (Huntingford and Kadri 2014). Today, a commonly used tool that can be used to assess farmed fish welfare is the monitoring of stress indicators (Conte 2004; Ellis et al. 2012). Furthermore, "good health" which is essential for "good welfare" can be defined as the ability of an organism to cope with stress (Segner et al. 2012). Chronic and/or repeated stress may also lead to exhaustion. This could be due to depletion of available energy through allostatic overload or to an inability to deal with the stress (McEwen and Wingfield 2010; Schreck 2010).

In stress and welfare assessment, problems often arise when trying to interpret variations in a single indicator because there may be multiple factors that influence these variations. Indeed, welfare should be interpreted as a global status (Huntingford and Kadri 2014). A solution would be to simultaneously record multiple indicators and then conduct a multivariate analysis of the results (North et al. 2006; Turnbull et al. 2005).

To our knowledge, the measurement of purely physiological indicators with multivariate analysis of the results has never been conducted in aquaculture studies. In this paper we investigate the physiological responses of Siberian sturgeon (Acipenser baerii), which is the most frequently farmed Acipenserid species in the world (Bronzi et al. 2011; Williot et al. 2001) and which is reared under diverse conditions. Dietary supplementation (with a prebiotic) followed by a chronic sublethal heat stress challenge were the scientific conditions that were tested in this study. Heat stress is a classic cause of stress in sturgeon (Kappenman et al. 2009; Linares-Casenave et al. 2013), whilst dietary supplementation is supposed to improve health status (Kiron 2012; Oliva-Teles 2012). Our hypothesis, is that prebiotic supplementation and chronic heat stress induce different levels of stress, health, and welfare in fish.

The aim of this study was to assess and evaluate the variations in physiological parameters to determine the physiological status of the fish. Plasma cortisol levels are one of the most frequently measured parameters used to evaluate stress and health status in sturgeon (Falahatkar et al. 2012; Ghomi et al. 2011; Williot et al. 2011; Wuertz et al. 2006; Zolfaghari et al. 2011). However, the use of cortisol has some limits. Indeed, the cortisol level is very sensitive and can vary depending upon the duration of handling, the type of handling technique, time of day, or the fasting procedure that is used (Allen and Cech 2007; Belanger et al. 2001; Martínez-Porchas et al. 2009). Monitoring fish in aquaculture leads to inevitable technical constraints and in general they cannot be sampled with a strict repeatable procedure. If cortisol is an informative physiological parameter under experimental conditions, it could, in aquaculture, lead to misinterpretations during the routine monitoring of stress and welfare. The parameters measured in this study are involved in immunity (lysozyme and complement activities), oxidative stress (total antioxidant capacity and the concentration of reactive oxygen metabolites), and cellular stress response (expression of heat shock proteins 70 and 90). In fishes, immune system analysis mainly focuses upon innate immunity which does not depend on prior exposure to a pathogen. Of the humoral factors, the most frequently monitored molecules are complement and lysozyme. Complement is composed of numerous proteins whose function is to aid in the phagocytosis or lysis of a pathogen (Whyte 2007). Lysozyme activity is often used as an immune indicator but also as an indicator of stress response in fish (Saurabh and Sahoo 2008). Oxidative stress is a disturbance in the balance between oxidant and antioxidant molecules, which could lead to oxidative damage (Costantini et al. 2010). Oxidant molecules, named reactive oxygen species (ROS), are a natural by-product of metabolism but can also occur 
as a consequence of stress induction. Due to the highly reactive nature of ROS it is easier to measure reactive oxygen metabolites (ROMs) when assessing oxidative damage. The antioxidant system is the defense mechanism against ROS. Antioxidant molecules can be obtained from the diet or via endogenous production (Monaghan et al. 2009). The total antioxidant capacity (TAC) represents the ability of the plasma to thwart oxidation without requiring the measurement of specific antioxidant molecules. Oxidative stress has deleterious effects upon proteins, lipids and DNA and persistent oxidative stress may lead to the appearance of pathologies, cellular senescence and aging (Costantini and Verhulst 2009). Heat-shock proteins (HSPs) are cellular mechanisms which react to any intense stress induction (Roberts et al. 2010). They also have been linked to basal metabolism and play an important role in stress acclimation (Basu et al. 2002; Sørensen et al. 2003). With the aim of providing an easier sampling procedure for fish farmers, all of the above parameters were investigated solely in blood samples.

The aim of this study was to evaluate whether the measurement of blood indicators was sufficient when assessing fish welfare, and whether HSP expression in erythrocytes can be used as a biomarker in sturgeon. We also sought to highlight the relevance of multivariate analysis to assess fish welfare from physiological parameters.

\section{Materials and methods}

Fish maintenance

Experiments were performed at the Institut Océanographique Paul Ricard, Embiez Island, France. Juvenile Siberian sturgeon, from a genitor pool, were provided by L'Ecloserie de Guyenne, France. They were randomly distributed in $20,100 \mathrm{~L}(60 \times 50 \times 34 \mathrm{~cm})$, fiberglass tanks with 5 fish per tank. The indoor rearing system was semi-closed with continuous filtration and daily exchange by overflow of $50 \mathrm{~L}$ of water per tank. Water quality parameters (dissolved oxygen $\left(\mathrm{O}_{2} \geq 90 \%\right)$, ammonium $\left(\mathrm{NH}_{4}^{+}<0.25 \mathrm{mg} \mathrm{L}{ }^{-1}\right)$, nitrate $\left(\mathrm{NO}_{3}{ }^{-}\right.$ $\left.<12.5 \mathrm{mg} \mathrm{mL}^{-1}\right)$ and nitrite $\left(\mathrm{NO}_{2}{ }^{-}<0.3 \mathrm{mg} \mathrm{mL}^{-1}\right)$ were measured daily in each tank. Temperature was continuously monitored and automatically thermo-regulated to $20^{\circ} \mathrm{C}$ (mean $20.1{ }^{\circ} \mathrm{C}$, $\min -\max$ 20.0-20.9 ${ }^{\circ} \mathrm{C}$ ). After acclimation and feeding of a control diet (Efico sigma 841, Biomar, France) for 6 weeks, the 4-month old fish weighed $52.2 \pm 1.3 \mathrm{~g}$ (mean $\pm \mathrm{SE}$ ) and measured $25.2 \pm 0.2 \mathrm{~cm}$ in length. Throughout the entire experimental period, the only mortality was due to accidental death of fish escaping from the tank. This study complied with the principles for the use and care of animals for research purposes, and with the French and European regulations on animal welfare.

\section{Experimental design}

Each group contained at least five replicates. Fish were fed three times a day with a ration of approximately $2 \%$ of their body weight. The experiment was divided into two phases: a dietary supplementation followed by a heat stress challenge (Fig. 1). During the first month, fish were divided into two groups: D1 was fed only with a control diet, and D2 with a control diet containing also a $\beta$-glucan type prebiotic $\left(\right.$ MacroGard $^{\circledR}$, Orffa,

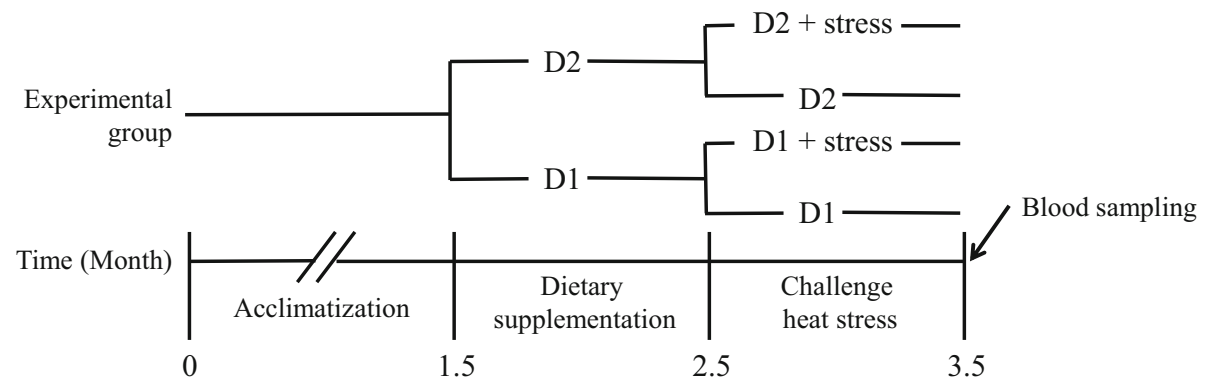

Fig. 1 Experimental design. D1 (control diet) and D2 (supplemented diet) 
Netherlands). The supplemented diet was prepared by coating in vegetable oil an equivalent of $12.5 \mathrm{mg} \mathrm{kg}$ wet weight of $\beta$-glucan. This preparation was then stored in hermetic bags at $16{ }^{\circ} \mathrm{C}$ until used. It was assumed that this supplementation could provide health benefits. After this initial period of treatment, half of the fish in $\mathrm{D} 1$ and in D2 were put under stress for 1 month by maintaining them at a sub-lethal temperature of $30^{\circ} \mathrm{C}$ (temperature increase at the beginning of the heat stress with a slope of $1{ }^{\circ} \mathrm{C} \mathrm{h}^{-1}$; temperatures during the heat stress: mean $30.1{ }^{\circ} \mathrm{C}$, min-max $29.4-30.9{ }^{\circ} \mathrm{C}$ ), whilst the remaining fish were maintained at $20{ }^{\circ} \mathrm{C}$. In the meantime, all fish were fed with a control diet. The tolerance range of Siberian sturgeon is $1-27{ }^{\circ} \mathrm{C}$ (Williot 2002). However, an extreme temperature of $30{ }^{\circ} \mathrm{C}$ can occur exceptionally in aquaculture, but this is associated with increased mortality (Brunel, personal data). This temperature was chosen to challenge the animal and push it to express a stress response.

Blood collection

Fish were anesthetized and $1 \mathrm{~mm}$ of blood was collected via a nonlethal caudal puncture and placed in a tube containing heparin. Heparinized blood was immediately centrifuged $\left(10 \mathrm{~min} ; 2500 \mathrm{~g} ; 4^{\circ} \mathrm{C}\right)$. Then, plasma was distributed into $50 \mu \mathrm{L}$ aliquots and conserved at $-80^{\circ} \mathrm{C}$. After removal of the remaining interphase between the supernatant and the cells, blood pellets were homogenized in two volumes of RNA before storage at $-80{ }^{\circ} \mathrm{C}$. Plasma aliquots were used to measure the lysozyme and complement activities, as well as the antioxidant and oxidant capacities. Red blood cells were used to measure $h s p 70$ and $h s p 90$ gene expression.

Cellular stress response

After an initial purification step that involved mixing Extract-All (Eurobio, France) and chloroform with samples, erythrocyte total RNA extraction was performed with a column extraction Kit (NucleoSpin 8 RNA, Macherey-Nagel, Germany). A supplementary rDNase treatment was carried out according to the manufacturer's instructions to remove any genomic DNA contamination. Genomic DNA contamination was excluded by a control PCR amplification of RNA. RNA integrity was controlled by migration of $3 \mu \mathrm{L}$ of RNA using a standard electrophoresis on a $1 \%$ agarose gel. Double-strand cDNA was synthesized from total RNA according to the manufacturer's manual (Omniscript ${ }^{\circledR}$, Qiagen, Germany). Real-time PCR quantifications (qPCR) were performed using SYBRgreen technology on a LightCycler 480 (Roche, Germany). The reaction mix consisted of $5 \mu \mathrm{L}$ of master mix (Roche, Germany), $1 \mu \mathrm{L}$ of each primer ( $1 \mu \mathrm{M}$ final), $1 \mu \mathrm{L}$ of molecular grade water and $2 \mu \mathrm{L}$ of cDNA. For qPCR controls, the template was replaced by molecular grade water. All assays were carried out in duplicate and a calibrator was added to standardize runs with each other. Primers were designed using Primer3Plus (http://primer3plus.com/) and Oligo Calc (http://www.basic.northwestern. edu/biotools/oligocalc.html) based on sequences available on GenBank from A. baerii for hsp70 (no. HM348777.1) and from sequences of A. schrenckii (no. JX477807.1) and A. ruthenus (no. JN700181.1) for hsp90. The following primers were used: hsp70-forward (5'-CATCCTGAACGTTTCTGCA-3'); hsp70-reverse (5'-TTCTCACGCTGCACATCATC-3'); hsp90-forward (5'-AATGACTGGGAGGACCATCT-3') and hsp90-reverse (5'-GTATTCTGGGATGAGCTCTT-3'). Specificity of the quantification assays was confirmed by migration on agarose gel of 15 amplification products and by the sequencing of two individual amplicons that were analyzed through a Blast search to confirm their identities. Sequence of A. baerii for hsp 90 was submitted to GenBank (no. KR011766). HSP expressions were normalized to $\beta$-actin with the primers actinforward (5'-TATCCTGACCCTGAAGTACCCAATC- $\left.3^{\prime}\right)$ and actin-reverse (5'-CACGCAGCTCATTGTAGAAGGTGTG-3'). In our four experimental groups the number of cycles ( $\mathrm{Ct}$ values) of $\beta$-actin were ranged between $17.6 \pm 0.2$ and $17.8 \pm 0.1 \mathrm{Ct}$. Here, our experimental conditions did not affect the $\mathrm{Ct}$ values (ANOVA, $p=0.77$ ) which means that $\beta$-actin was a valid reference gene for our experiment.

The PCR conditions for both HSP and for the $\beta$-actin were an initial denaturation at $95{ }^{\circ} \mathrm{C}$ for $10 \mathrm{~min}$ followed by 50 amplification cycles at $95{ }^{\circ} \mathrm{C}$ for $10 \mathrm{~s}, 58{ }^{\circ} \mathrm{C}$ for $20 \mathrm{~s}$ and $72{ }^{\circ} \mathrm{C}$ for $35 \mathrm{~s}$. After each experiment, melting curves for every sample were analyzed to verify whether there was any by-product amplification. 
Immunity parameters

Plasma lysozyme activity was measured according to Eslamloo et al. (2012), with modifications. A suspension of lyophilized Micrococcus lysodeikticus $\left(0.5 \mathrm{mg} \mathrm{mL}^{-1}\right)$ was prepared in PBS (66 mM, $0.1 \% \mathrm{NaCl}, \mathrm{pH} \mathrm{6.2)}$ put on ice and kept away from the light. $100 \mu \mathrm{L}$ of this suspension was mixed with $15 \mu \mathrm{L}$ of plasma in a 96-well microtiter plate. All assays were carried out in triplicate. Hen egg-white lysozyme was used to obtain the standard curve. Absorbance was measured at $450 \mathrm{~nm}$ every $15 \mathrm{~s}$ for $7 \mathrm{~min}$. Absorbance reduction depends on the lysis of M. lysodeikticus cells by the lysozyme.

The hemolytic activity of the alternative complement pathway (ACP) was tested by a previously described microplate method (Bado-Nilles et al. 2009) and adapted for sturgeon plasma. Briefly, rabbit red blood cells (RBC, Biomérieux, France) were washed in a gelatin veronal buffer (GVB: $0.1 \%$ Gelatin, Veronal Sordalab France) and diluted to a concentration of $2 \%$ in EGTA-Mg-GVB buffer (10 mM EGTA, $20 \mathrm{mM} \mathrm{MgCl}_{2}$, $17.5 \mathrm{mM} \mathrm{NaOH}, \mathrm{GVB})$. Sturgeon plasma diluted 1/10 in GVB was added in increasing amounts, from 10 to $100 \mu \mathrm{L}$ to the microplate wells. The wells were filled with EGTA-Mg-GVB buffer to a final volume of 100 and $50 \mu \mathrm{L}$ of $2 \%$ RBC suspension was added. 100 and $0 \%$ hemolysis controls were obtained using $100 \mu \mathrm{L}$ of ultrapure water and $100 \mu \mathrm{L}$ of buffer EGTA-Mg-GVB respectively. The samples were incubated at $20{ }^{\circ} \mathrm{C}$ for $60 \mathrm{~min}$ and centrifuged $\left(500 \mathrm{~g} ; 5 \mathrm{~min} ; 4^{\circ} \mathrm{C}\right)$. Finally, $75 \mu \mathrm{L}$ of supernatant from each well was transferred to a new flat-bottom microplate and $75 \mu \mathrm{L}$ of PBS pH 7.2 was added and absorbance at $450 \mathrm{~nm}$ was read. The percentage of lysis for each sample and each dilution was calculated using control values. The dilution that would produce $50 \%$ lysis was determined by probit analysis and results were expressed as ACH50 (units $\mathrm{mL}^{-1}$ ).

\section{Oxidative stress}

Plasma antioxidant defense was evaluated using the commercial Oxiselect Total Antioxidant Capacity (TAC) assay kit (Cell Biolabs, Inc, USA), according to the manufacturer's instructions. Similar procedures were used successfully in Chinese sturgeon (Acipenser sinensis) (Feng et al. 2012). This assay measures the antioxidant power of biomolecules via the ability of plasma to reduce $\mathrm{Cu}^{2+}$ to $\mathrm{Cu}^{+}$. Reduced copper reacts with a chromogen and final absorbance measured at $490 \mathrm{~nm}$ is proportional to TAC. This reaction was performed in a 96-well microtiter plate. Results were expressed as $\mu \mathrm{M}$ copper reducing equivalents (CRE). All samples were assayed in duplicate from plasma diluted $1 / 3$ in $1 \times$ PBS and compared to a standard uric acid range.

The plasma concentration of reactive oxygen metabolites (ROMs) was measured using the commercial d-ROMs test (Diacron International, Italy). The d-ROMs measured mostly hydroperoxides which are intermediate peroxidation products of lipids, proteins and nucleic acids, thus indicating the level of exposure to oxidant molecules. All procedures conform to the manufacturer's protocol except for the adaptation of the micro method for fish, described by Bagni et al. (2007). $10 \mu \mathrm{L}$ of plasma was used per reaction and tests were performed in duplicate. Results were expressed as ng of $\mathrm{H}_{2} \mathrm{O}_{2} \mu \mathrm{L}^{-1}$.

Data analysis

For HSP expression, normality and homoscedasticity were reached only after a square-root transformation, while all the other variables were normally distributed without transformation. For each measured parameter, the effects of diet, stress, and their interactions were tested with two-way ANOVA followed by post hoc comparison of Student-Newman-Keuls (SNK). For the analysis of the dependence between two parameters, the Pearson correlation was used. As oxidant (ROMs) and antioxidant (TAC) molecules were significantly correlated, we used the ratio $(\mathrm{ROMs} / \mathrm{TAC}) \times 1000$ to illustrate the level of oxidative stress according to Costantini et al. (2006). A square-root transformation was applied to these results to reach normality and homoscedasticity. To estimate the relationship between more than two parameters we performed a principal component analysis (PCA) based on ranked values to further reduce dimensionality. The variables that we used were $h s p 90$ and $h s p 70$ expressions, lysozyme and complement activities, antioxidant capacity, and ROMs. Oxidative stress was included as an illustrative variable (not involved in the construction of the principal components). The rearing condition was fixed on the PCA to detect the existence of patterns among fish. Box plots were performed with GraphPad Prism 5 (GraphPad Software, Inc, USA). Univariate and 
multivariate analysis were carried out using the program R version 3.1.2 (R Core Team 2014, Austria) with the Rcmdr (Fox 2005) and FactoMineR (Lê et al. 2008) R packages. All tests were two-tailed and $p$ values $<0.05$ were considered significant. Mean values are given as $\pm \mathrm{SE}$.

\section{Results}

Cellular stress response

The expression levels of HSP in erythrocytes were variable between the four groups of fish (Table 1; Fig. 2). For $h s p 90$, a significant interaction between factors could be detected ( $p=0.012$ ) (Fig. 2a). In unchallenged fish, the level of $h s p 90$ expression in fish fed with D2 was lower than in fish fed with the control diet $(p=0.024)$. Environmental stress induced a clear increase in $h s p 90$ expression compared to control fish regardless of the diet $(p<0.001)$. The levels of $h s p 70$ expression fluctuated greatly between the different experimental conditions (Fig. 2b). Diet and stress interact in $h s p 70$ expression $(p<0.0001)$. In controls, $h s p 70$ expression was lower in fish fed with D2 than in fish fed with D1 $(p<0.0001)$. The opposite trend was observed with the two groups maintained under stress conditions $(p<0.0001)$. Under heat stress, a decrease of $h s p 70$ expression was observed for D1 fish fed with the control diet $(p=0.0003)$ while there was a more than twofold increase in $h s p 70$ expression for D2 fish fed with the supplemented diet $(p<0.0001)$.

Immunity parameters

Both lysozyme and complement activities in plasma were impacted by heat stress (Table 1). The complement activity increased 1.6-fold under stress conditions regardless of the diet $(p<0.0001)$. The lysozyme activity decreased 1.7-fold, in the presence of stress, in fish that did not receive the supplemented diet $(p=0.0002)$. However, there is no dietary effect or any interaction between diet and stress observed with both lysozyme and complement activities.

\section{Oxidative stress}

The antioxidant and oxidant capacities of the plasma were also impacted by heat stress (Table 1). The ROMs were equivalent in the D1 and D2 treatment groups and demonstrated a 1.5-fold decrease under stress conditions compared to the control $(p<0.0001)$. There is an interaction between diet and stress for the TAC ( $p=0.004)$, with different responses to the stress challenge depending upon the diet. The TAC were similar

Table 1 Effects of rearing conditions on blood parameters in Siberian sturgeon

\begin{tabular}{|c|c|c|c|c|}
\hline \multirow[t]{2}{*}{ Parameters } & \multicolumn{2}{|l|}{ Control } & \multicolumn{2}{|c|}{ Environmental stress } \\
\hline & D1 $(n=30)$ & $\mathrm{D} 2(n=22)$ & D1 $(n=20)$ & $\mathrm{D} 2(n=21)$ \\
\hline \multicolumn{5}{|l|}{ Cellular stress response } \\
\hline $\begin{array}{l}\text { hsp } 90 \text { (square-root transformation of relative } \\
\text { expression to } \beta \text {-actin) }\end{array}$ & $1.23 \pm 0.07^{\mathrm{a}}$ & $0.98 \pm 0.10^{\mathrm{b}}$ & $1.59 \pm 0.09^{c}$ & $1.75 \pm 0.13^{\mathrm{c}}$ \\
\hline $\begin{array}{l}\text { hsp } 70 \text { (square-root transformation of relative } \\
\text { expression to } \beta \text {-actin) }\end{array}$ & $1.13 \pm 0.06^{\mathrm{a}}$ & $0.66 \pm 0.05^{\mathrm{b}}$ & $0.78 \pm 0.12^{\mathrm{b}}$ & $1.55 \pm 0.11^{\mathrm{c}}$ \\
\hline \multicolumn{5}{|l|}{ Immunity } \\
\hline Lysozyme $\left(\mu \mathrm{g} \mathrm{mL}^{-1}\right)$ & $4.61 \pm 0.32^{\mathrm{a}}$ & $4.84 \pm 0.49^{\mathrm{a}}$ & $2.71 \pm 0.36^{\mathrm{b}}$ & $3.69 \pm 0.50^{\mathrm{ab}}$ \\
\hline Complement (ACH50 $\mathrm{U} \mathrm{mL}^{-1}$ ) & $12.39 \pm 0.83^{\mathrm{a}}$ & $13.14 \pm 1.02^{\mathrm{a}}$ & $21.47 \pm 2.09^{b}$ & $20.33 \pm 2.44^{\mathrm{b}}$ \\
\hline \multicolumn{5}{|l|}{ Oxidative stress } \\
\hline Antioxidant capacity (CRE) & $492.04 \pm 23.59^{\mathrm{a}}$ & $497.36 \pm 39.29^{\mathrm{a}}$ & $791.51 \pm 64.92^{\mathrm{b}}$ & $1067.11 \pm 114.46^{\mathrm{c}}$ \\
\hline ROMs (ng $\mathrm{H}_{2} \mathrm{O}_{2} \mu \mathrm{L}^{-1}$ ) & $67.12 \pm 4.54^{\mathrm{a}}$ & $69.45 \pm 5.58^{\mathrm{a}}$ & $46.93 \pm 2.83^{\mathrm{b}}$ & $43.63 \pm 2.74^{\mathrm{b}}$ \\
\hline
\end{tabular}

Values are mean \pm SE. Mean values with different superscripts indicate significant difference following SNK multiple comparison test $(p<0.05)$ 

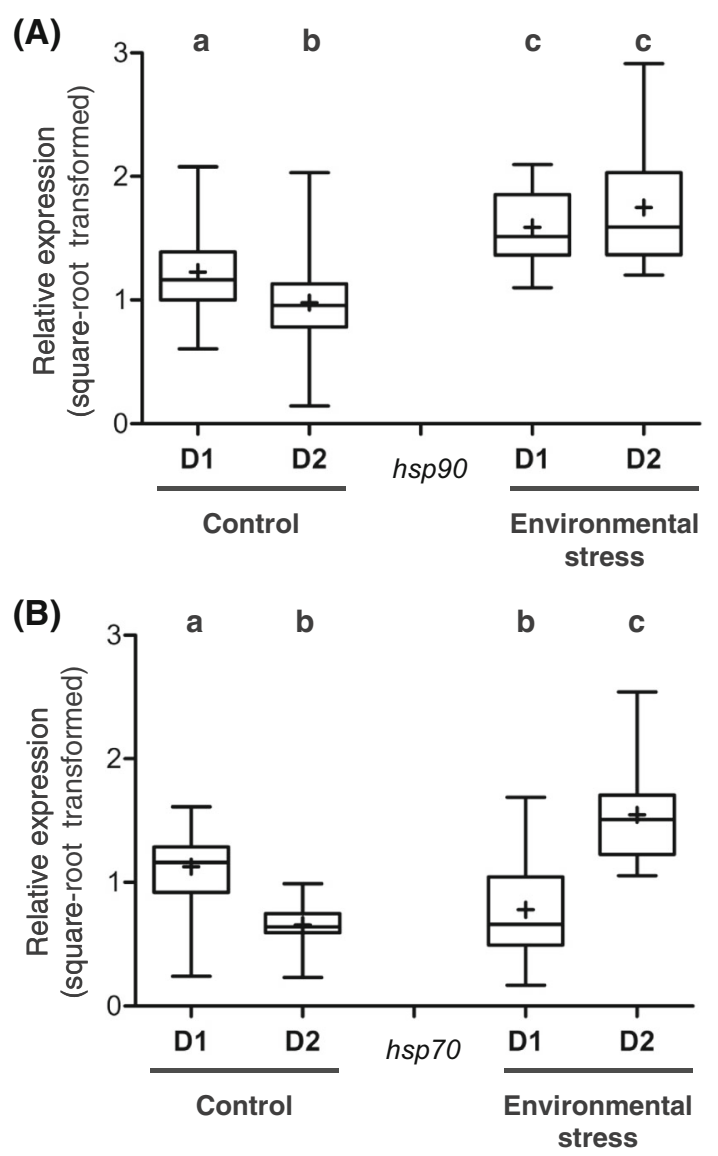

Fig. 2 Boxplots of heat shock protein expression. a hsp 90 expression and $\mathbf{b}$ hsp 70 expression. Crosses indicate means, while boxes indicate 75th percentile (top line), median (middle line), 25th percentile (bottom line) and error bars indicate extreme values of data range. Different superscripts indicate significant differences among conditions (SNK multiple comparison test, $p<0.05)$

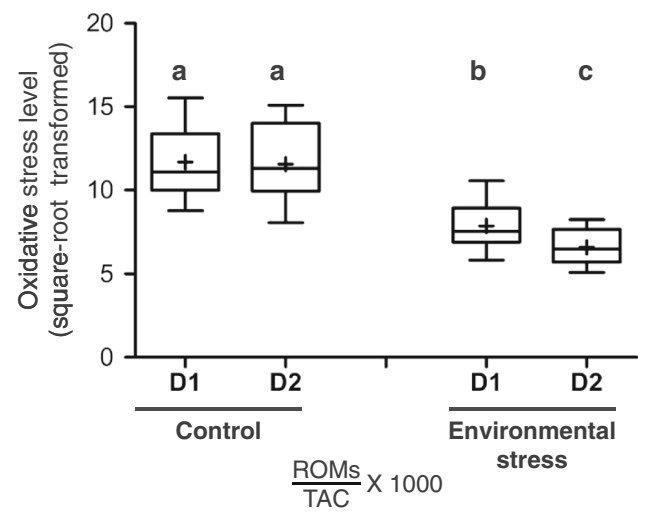

Fig. 3 Relationship between the level of oxidative stress $[(\mathrm{ROMs} / \mathrm{TAC}) \times 1000]$ and the rearing condition. Crosses indicate means, while boxes indicate 75th percentile (top line), median (middle line), 25th percentile (bottom line) and error bars indicate extreme values of data range. Different superscripts indicate significant differences among conditions (SNK multiple comparison test, $p<0.05)$

for D1 and D2 in the control rearing condition, but under a stress challenge this level increases 1.6-fold for D1 $(p<0.0001)$ and more than 2.1 -fold for fish fed with a supplemented diet $(p<0.0001)$. A correlation was established between TAC and ROM values $(p=0.003)$ and oxidative stress levels are presented in Fig. 3. 
Interestingly, oxidative stress was higher in the control rearing group than in the stress group $(p<0.0001)$ and a lower oxidative stress level was observed for fish that received supplementation $(p=0.032)$.

Multivariate analysis

Using a PCA with six variables we obtained two relevant principal components (PCs) with an eigenvalue above 1, which explained $62 \%$ of the overall variance in the data (Fig. 4). The PCA shows correlations between all the variables (Fig. 4a). With regard to multivariate analysis we see an inverse relationship between the lysozyme and complement activities and also between oxidant and antioxidant levels. In addition to $h s p 70$ and $h s p 90$ expression these parameters all contributed highly to the construction of the PCs, so were
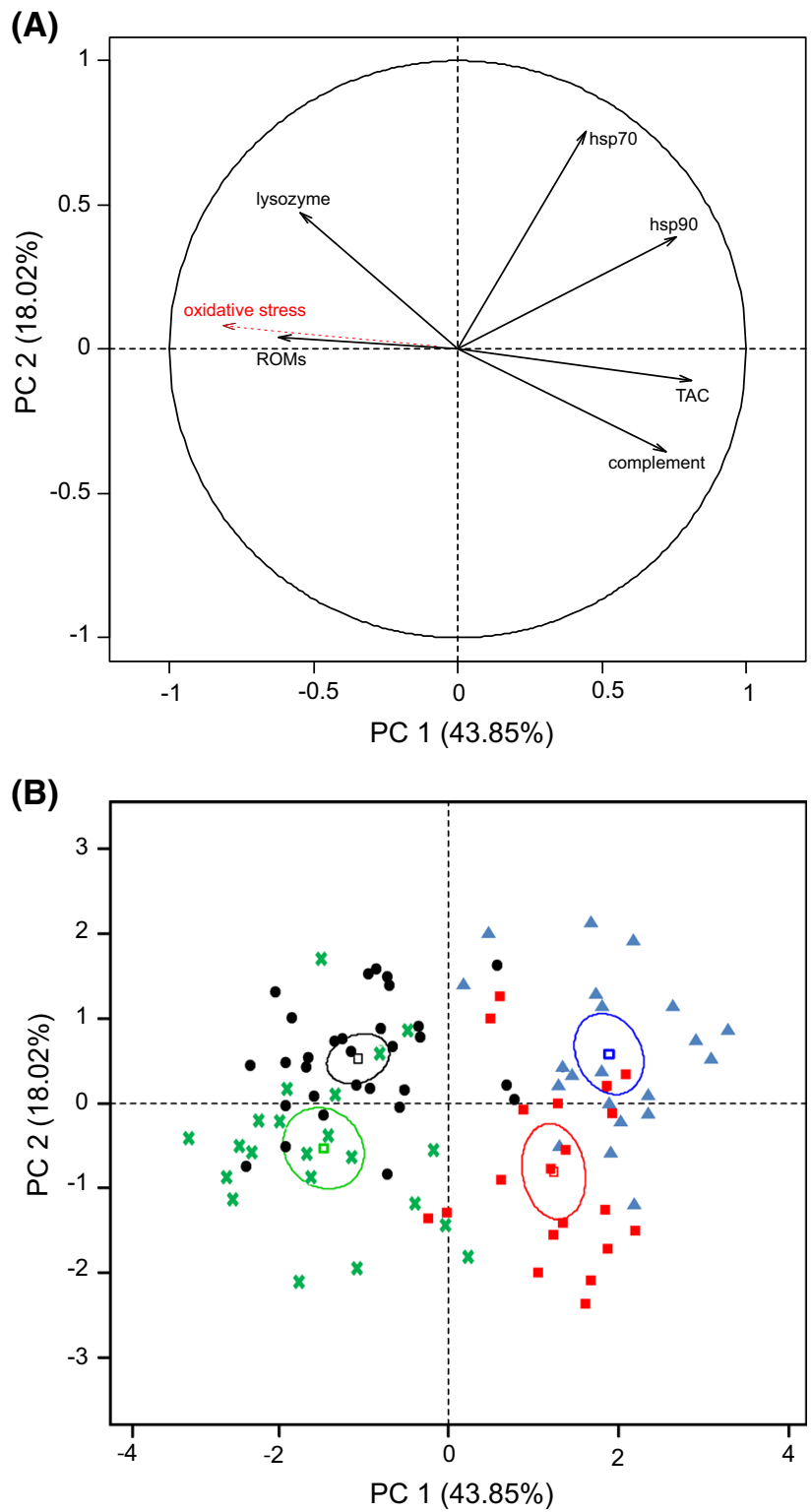

Fig. 4 Principal component analysis performed on six physiological variables for every rearing condition. Plotted according to the first two principal components (PCs). a Each active variable is represented by a black arrow and illustrative variables (not involved in the construction of PCs) by a red dotted arrow. b Each fish is represented by a dot. Black circles and green crosses are for fish fed with D1 and D2 respectively in the absence of stress. Red squares and blue triangles are for fish fed with D1 and D2 respectively in the presence of stress. The barycentre of each group of fish is represented by a square surrounded by a confidence ellipse 
all informative in the fish distribution. The illustrative variables demonstrated that oxidative stress was correlated with the two parameters used to calculate it, as might be expected. The PCA was also used to visualize the presence of patterns among the fish (Fig. 4b). The six parameters included in this analysis ( $h s p 90$ and $h s p 70$ expressions, lysozyme and complement activities, TAC and ROMs) enabled the four experimental groups of fish to be discriminated. Environmental stress induced physiological responses that were clearly different when compared to the fish raised under control conditions. The effect of dietary supplementation is less evident but remains important enough to induce observable physiological modifications compared to fish fed with the control diet in the PCA.

\section{Discussion}

The main goal was to measure various physiological parameters to determine their potential relevance to the assessment of heat stress, health status and welfare in Siberian sturgeon in aquaculture. This study was not designed to evaluate the effects of temperature stress or $\beta$-glucan in sturgeon. We assume that dietary supplementation with $\beta$-glucan, at a commercial dose, could increase health status, whilst maintaining sturgeon at a sublethal temperature decreases their health and welfare.

All of the parameters investigated in this study were carried out from blood samples. This method of sampling is particularly interesting in sturgeon species as it avoids killing valuable females to collect tissue. The collection of blood samples enables repeated sampling to be performed which has the advantage of making it possible to follow the evolution of intra-individual data.

The heat-shock proteins are classic cellular stress biomarkers. Intense stress induces their expression and they are also known to play an important role in fish health (Feder and Hofmann 1999; Roberts et al. 2010). The level of HSP expression is tissue-dependent (Wang et al. 2013) and in sturgeon, to our knowledge, this article is the first to record HSP expression in erythrocytes (Table 2). This first assessment enables us to validate whether HSP expression in erythrocytes can be a good indicator of stress and health status in sturgeon. In salmonids the measurement of HSP expression from erythrocytes to evaluate stress response has already been performed successfully (Currie and Tufts 1997; Lund et al. 2002). In Siberian sturgeon, we show that the level of expression of $h s p 70$ and $h s p 90$ was variable under all experimental conditions with an interaction between diet and heat stress challenge. This means that HSP expression following a stress challenge may be dependent upon dietary supplementation.

Even though the interaction is significant, the increase of hsp90 expression under stress conditions is also worth paying attention to because it holds true with both diets. The same trend was found in the literature with various sturgeon species and tissues (see Table 2 for details on species, tissues and HSP). HSP protein levels increase as a consequence of heat stress (Allen et al. 2006; Deng et al. 2009; Han et al. 2012; LinaresCasenave et al. 2013; Silvestre et al. 2010; Wang et al. 2013; Werner et al. 2007; Zheng et al. 2015), acute cold stress, air exposure (Wang et al. 2013), and contamination (Keyvanshokooh et al. 2009), but not during salinity acclimation (Sardella and Kültz 2009). Hsp mRNA expression increases with high stocking density or after an acute hypoxic stress (Ni et al. 2014). HSP induction following stress is also a classical observation in other fish species (Basu et al. 2002; Deane and Woo 2011). HSPs are important chaperone proteins involved in folding, translocation, aggregation, repair, and degradation of other proteins (Deane and Woo 2011; Roberts et al. 2010). Thus, neo-synthesised HSP chaperone proteins and an increase in HSPs helps to limit misfolding and inappropriate aggregations of other proteins in cells exposed to stress. HSPs are important for recovery and survival of an organism. Therefore, under stress, when an organism produces higher levels of HSPs, it can be interpreted that up-regulation is giving rise to a better cellular defense mechanism (Sørensen et al. 2003). In our study, the hsp70 expression under heat stress challenge is diet dependant. Stressed fish belonging to the D2 group displayed a higher $h s p 70$ expression compared to those in the D1 group. This result could indicate that fish fed with a supplemented diet for 1 month became more able to cope with a stress event. However, without comparison with other physiological parameters, we cannot conclude that there is a possibility that the supplemented group of fish was more damaged than those receiving the control diet. This demonstrates the importance of measuring different physiological compartments to assess welfare. The enhancement of antioxidant defenses and the resistance of depletion in lysozyme activity in the stressed D2 group compared to the stressed D1 group enables us to exclude the damage hypothesis. An opposite trend was observed in the 
Table 2 Synthesis of existing literature on the evaluation of heat shock proteins in sturgeon

\begin{tabular}{|c|c|c|c|}
\hline Refs. & $\begin{array}{l}\text { Experimental design, species/tissue sampled } \\
\text { condition (dose/length) }\end{array}$ & HSPs & Results \\
\hline Werner et al. (2007) & $\begin{array}{l}\text { Green sturgeon/whole larvae } \\
\text { Heat shock }\left(26{ }^{\circ} \mathrm{C} / 3 \text { days-YSA }\right)\end{array}$ & $\begin{array}{l}\text { Protein } \\
60 ; 72 \\
78 ; 89\end{array}$ & $\begin{array}{l}\text { level } \\
\nearrow \text { except for HSP60 }\end{array}$ \\
\hline $\begin{array}{l}\text { Linares-Casenave } \\
\text { et al. (2013) }\end{array}$ & $\begin{array}{l}\text { Green sturgeon/whole larvae } \\
\text { Heat shock }\left(20-28{ }^{\circ} \mathrm{C} / 24 \text { h-YSA }\right)\end{array}$ & $\begin{array}{l}60 ; 72 \\
78 ; 89\end{array}$ & $\nearrow$ Over time the $\nearrow$ is lower \\
\hline Zheng et al. (2015) & $\begin{array}{l}\text { Green sturgeon/liver, muscle } \\
\text { Feeding rate }\left(2-15 \% \text { BW day }{ }^{-1} / 1 \text { week }\right) \\
\text { Heat shock }\left(28^{\circ} \mathrm{C} / 4 \mathrm{~h}\right)\end{array}$ & 70 & $\begin{array}{l}\text { Feeding rate: } \searrow \text { in lower feeding rates in } \\
\text { muscle only } \\
\text { Heat shock: }\end{array}$ \\
\hline Allen et al. (2006) & $\begin{array}{l}\text { Green sturgeon/muscle, fin } \\
\text { Heat shock }\left(24^{\circ} \mathrm{C} / 2.5-5 \text { weeks }\right)\end{array}$ & $\begin{array}{l}60 ; 72 \\
78 ; 90\end{array}$ & $\nearrow$ in muscle or fin except for HSP60 \\
\hline $\begin{array}{l}\text { Sardella and Kültz } \\
\text { (2009) }\end{array}$ & $\begin{array}{l}\text { Green sturgeon/gill } \\
\text { Salinity acclimation }\left(15-24 \mathrm{~g} \mathrm{~L}^{-1} / 2 \text { weeks }\right)\end{array}$ & $\begin{array}{l}60 ; 70 \\
90\end{array}$ & $\leftrightarrow$ \\
\hline Han et al. (2012) & $\begin{array}{l}\text { White sturgeon/whole larvae } \\
\text { Starvation }(24-72 \mathrm{~h}) \\
\text { Heat shock }\left(26^{\circ} \mathrm{C} / 4 \mathrm{~h}\right)\end{array}$ & $70 ; 90$ & $\begin{array}{l}\text { Starvation: } \searrow \text { HSP90 only } \\
\text { Heat shock: } \nearrow \text {. Globally smaller for starved fish }\end{array}$ \\
\hline Deng et al. (2009) & $\begin{array}{l}\text { White sturgeon/liver } \\
\text { Feeding rate }\left(5-25 \% \mathrm{BW} \text { day }{ }^{-1} / 2 \text { weeks }\right) \\
\text { Heat shock }\left(26^{\circ} \mathrm{C} / 4 \mathrm{~h}\right)\end{array}$ & $60 ; 70$ & $\begin{array}{l}\text { Feeding rate: } \searrow \text { in lower feeding rate } \\
\text { Heat shock: } \nearrow\end{array}$ \\
\hline $\begin{array}{l}\text { Silvestre et al. } \\
\text { (2010) }\end{array}$ & $\begin{array}{l}\text { Green sturgeon, white sturgeon/whole larvae } \\
\text { Selenium intoxication }\left(8 \mu \mathrm{g} \mathrm{g}^{-1} / 8-12 \text { days }\right) \\
\text { Heat shock }\left(26^{\circ} \mathrm{C} / 8 \text { days }\right)\end{array}$ & 90 & $\begin{array}{l}\text { Selenium intoxication: } \leftrightarrow \\
\text { Heat shock: } \nearrow \text {. Over activation by intoxication }\end{array}$ \\
\hline Wang et al. (2013) & $\begin{array}{l}\text { Green sturgeon, White sturgeon/ } \\
\text { Mucus, heart, liver, GIT, gill, spleen, muscle } \\
\text { Heat shock }\left(26^{\circ} \mathrm{C} / 4 \mathrm{~h}\right) \\
\text { Cold shock }\left(10^{\circ} \mathrm{C} / 4 \mathrm{~h}\right) \\
\text { Air exposure }(5 \mathrm{~min}) \\
\text { Food deprivation (1 week) }\end{array}$ & 70 & $\begin{array}{l}\text { Heat shock: } \nearrow \text {. Variable according to species } \\
\text { Cold shock, air exposure: mainly } \nearrow \text { but variable } \\
\text { according to tissue } \\
\text { Food deprivation: variable according to tissue } \\
\text { and species }\end{array}$ \\
\hline $\begin{array}{l}\text { Keyvanshokooh } \\
\text { et al. (2009) }\end{array}$ & $\begin{array}{l}\text { Beluga/brain } \\
\text { Methylmercury intoxication }(0.8 \mathrm{ppm} / \\
70 \text { days })\end{array}$ & 70 & $\nearrow$ \\
\hline & & mRNA & expression \\
\hline Ni et al. (2014) & $\begin{array}{l}\text { Amur sturgeon/liver, spleen, kidney } \\
\text { Crowding (6.9-9.3 } \mathrm{kg} \mathrm{m}^{-3} / 20-60 \text { days) } \\
\text { Hypoxia }\left(3-1 \mathrm{mgO}_{2} \mathrm{~L}^{-1} / 0.5-6 \mathrm{~h}\right)\end{array}$ & $70 ; 90$ & $\begin{array}{l}\text { Crowding, Hypoxia: } \nearrow \text {. Difference between } \\
\text { tissues and between } H \text { sps }\end{array}$ \\
\hline This paper & $\begin{array}{l}\text { Siberian sturgeon/erythrocyte } \\
\text { Dietary supplementation } \\
\left.\text { (12.5 mg } \beta \text {-glucans.kg }{ }^{-1} / 1 \text { month }\right) \\
\text { Heat shock }\left(30^{\circ} \mathrm{C} / 4 \text { weeks }\right)\end{array}$ & $70 ; 90$ & $\begin{array}{l}\text { Dietary supplementation: } \searrow \\
\text { Heat shock: } \nearrow h s p 90 \text {. Variable for } h s p 70 \\
\text { according to diet }\end{array}$ \\
\hline
\end{tabular}

Main results are briefly summarized. Symbols and abbreviations are: decrease (square); increase (square); stable (left-right arrow); yolk-sac absorption (YSA); body weight per day $\left(\mathrm{BW} \mathrm{day}^{-1)}\right.$; gastrointestinal tract (GIT)

stress challenged D1 group, with a decrease of $h s p 70$ mRNA expression. When one considers that acclimation to sublethal temperature is highly difficult, this result could indicate a state of early physiological exhaustion. Hsp70 and to a lesser extent hsp90 play an important role in cellular survival in chronic stress situations (Basu et al. 2002; Beere 2004; Kalmar and Greensmith 2009; Roberts et al. 2010). The observed decrease may indicate the appearance of irreversible cellular damage.

Interestingly, for both $h s p 70$ and $h s p 90$, the basal expression level was lower for fish fed with the supplemented diet compared to the D1 group fish. These results could be explained by a lower metabolic rate due 
to the lack of nutrients or starvation (Han et al. 2012). In rainbow trout (Oncorhynchus mykiss), supplementation with selenomethionine reduces the negative performance impact of overcrowding but decreases hsp70 expression in muscle compared to the basal expression level and stress expression level in diet controls (Küçükbay et al. 2009). In our study the low basal expression level has no impact upon the fishes' capacity to induce an efficient HSP response under stress conditions. Thus, a low basal HSP expression level should not be interpreted here as a decrease in metabolism or health.

Depending upon the fish species and the study, it has been shown that dietary administration of $\beta$-glucan enhances or does not alter lysozyme or complement activities (Kiron 2012). For other kinds of supplementation the lysozyme or complement activities are also variable in Siberian sturgeon (Eslamloo et al. 2012; Geraylou et al. 2012, 2013; Kolman 2001; Xie et al. 2006). In our study, both lysozyme and complement activities are unmodified by dietary supplementation. However, sturgeon fed with $\beta$-glucan showed slightly better resistance to lysozyme depletion due to chronic heat stress than the control group. In Beluga (Huso huso) a similar result was found with lysozyme. Exposure to a sublethal dose of pollutant induces a decrease in lysozyme activity after 35 days with the control diet and only after 63 days in fish supplemented with $\beta$ glucan (Khoshbavar-Rostami et al. 2006). In addition to its important role in the innate immune system, the function of lysozyme is known to vary according to the intensity, duration and type of induced stress (Saurabh and Sahoo 2008). Furthermore, following acute stress, lysozyme activity increases with a maximal peak at $9 \mathrm{~h}$ post-stress in Siberian sturgeon (Eslamloo and Falahatkar 2014). In our study, we show that chronic heat stress leads to a decrease in lysozyme activity. PCA analysis demonstrates that lysozyme and complement activities are negatively related (Fig. 4a). The increase in complement activity under heat stress conditions is an unexpected result: generally stress brings about a decrease in complement activity (Boshra et al. 2006; Holland and Lambris 2002). Further research should be conducted to assess the modulation of complement activity in Siberian sturgeon under various conditions and intensities of stress.

Oxidative stress plays an important role in sturgeon as it does in other organisms. Indeed, in Adriatic sturgeon (Acipenser naccarii), antioxidant enzymes appear in the early stages of life (Díaz et al. 2010) and dietary supplementation with oxidized lipids induces deformation and mortality in Siberian sturgeon larvae (Fontagné et al. 2006). In our study, the level of antioxidants increases with heat stress for D1 and D2. However, there is a significant diet effect in the stress challenge response, with more antioxidants present in the D2 group than in the control group, resulting in a lower oxidative stress in the supplement fed fish. This result indicates that the antioxidant compounds have a protective effect under stress conditions, which leads to better health status in the supplemented fish. When there was no stress the benefit of $\beta$-glucan supplementation was not observable in the oxidative stress level of the Siberian sturgeon.

Numerous physiological modifications made by an organism during stress acclimation require extra energy. If the energy demand exceeds the available energy, allostatic overload will progressively induce a generalized system collapse (McEwen and Wingfield 2003; Schreck 2010). Thus, between two comparable fish, the one with a better health and welfare status can cope more efficiently with stress (Segner et al. 2012). In our study, the relevance of dietary supplementation, health status, and welfare conditions is more pertinent after a stress challenge. We have also shown that a selection of physiological parameters could be used to assess heat stress, health status and welfare in Siberian sturgeon. In univariate analysis the effects of stress on each measured physiological indicator were highly significant, but not the effects of diet (except for $h s p 70$ and $h s p 90$ ), or the interaction between diet and stress (except for both $h s p$ and TAC). When assessing welfare, there is more to consider than just the stress reaction. To include all parameters and conditions in a single analysis we used a PCA, which enabled all of the patterns among the fish to be clearly represented (Fig. 4b).

Multivariate analysis has already been successfully used to assess the stress and welfare of fish but has never been employed solely for the monitoring of physiological parameters (Adams et al. 2007; Di Marco et al. 2008; North et al. 2006; Turnbull et al. 2005). All of the measured parameters were complementary and highly informative in discriminating between the four experimental conditions that included different stress status, health status, and welfare. Our understanding of the reactions of specific physiological parameters is still largely lacking in fish and especially so in sturgeon. Stress, health status, and function-based welfare determination should only be undertaken once the assessment of diverse physiological measurements have been made. Moreover, variation in a specific parameter must be interpreted with caution because each parameter has many functions, actions and regulation pathways. The relationship between parameters is also important and should be assessed. This point is well illustrated in the case of oxidative stress, which results 
from the imbalance between the production of reactive oxygen species and the capacity of the organism's antioxidant system to counteract these (Monaghan et al. 2009). To establish the level of oxidative stress in an organism, it is strongly recommended that the antioxidant and oxidant capacities are compared together (Costantini and Verhulst 2009). Here, we show that parameters involved in cellular stress response and immunity could be enhanced or depleted differently according to the levels of stress and the health status of the fish (e.g., a decrease in lysozyme activity and an increase in complement activity under stress challenge). If the variation of one parameter is difficult to interpret, the covariation of the whole set of physiological indicators represented in the PCA definitely depends on our experimental conditions.

Fish farmers could use a method similar to the one presented in this article to estimate the level of fish stress and welfare, thus helping them to prevent the short and long-term negative impacts of allostatic overload. Monitoring is of particular interest in sturgeon farming, mainly dedicated to caviar production, because egg quality and quantity are impacted by stress and energy allocation (Schreck 2010; Schreck et al. 2001).

\section{Conclusion}

Both stress and dietary supplementation modulated the transcription of $h s p 70$ and $h s p 90$ in Siberian sturgeon erythrocytes. For the other measured physiological parameters, the beneficial effect of dietary supplementation on health and welfare was mainly observable after a heat stress challenge. The use of blood samples to assess the physiological indicators involved in cellular stress response, immunity, and oxidative stress seems adequate to evaluate heat stress. Estimation of fish welfare may also be achieved with these physiological parameters mainly thanks to multivariate analysis.

Acknowledgments We would like to thank the staff at the Institut Océanographique Paul Ricard for their support, L'écloserie de Guyenne for generously providing sturgeon and the PACA which funded this study. We particularly thank Olivier Brunel from the Sturgeon SCEA Company and Stéphane Coupé for their invaluable advice as well as Aden Smith for the English corrections. We thank the two anonymous referees for helpful comments on the manuscript.

Author contribution statement RS and SG designed the study. RS conducted the zootechnical and laboratory experiments. SR, NPA and SG contributed to laboratory analyses. TM contributed to zootechnical analyses. RS, SG and SR analyzed the data. RS wrote the manuscript and SG, SR, NPA and TM commented on the manuscript.

\section{Compliance with ethical standards}

Conflict of interest The authors have declared that no financial or non-financial competing interests exist.

Open Access This article is distributed under the terms of the Creative Commons Attribution 4.0 International License (http:// creativecommons.org/licenses/by/4.0/), which permits unrestricted use, distribution, and reproduction in any medium, provided you give appropriate credit to the original author(s) and the source, provide a link to the Creative Commons license, and indicate if changes were made.

\section{References}

Adams CE, Turnbull JF, Bell A, Bron JE, Huntingford F (2007) Multiple determinants of welfare in farmed fish: stocking density, disturbance, and aggression in Atlantic salmon (Salmo salar). Can J Fish Aquat Sci 64:336-344. doi:10.1139/f07-018

Allen PJ, Cech JJ (2007) Age/size effects on juvenile green sturgeon, Acipenser medirostris, oxygen consumption, growth, and osmoregulation in saline environments. Environ Biol Fish 79:211-229. doi:10.1007/s10641-006-9049-9

Allen PJ, Hodge B, Werner I, Cech JJ Jr (2006) Effects of ontogeny, season, and temperature on the swimming performance of juvenile green sturgeon (Acipenser medirostris). Can J Fish Aquat Sci 63:1360-1369

Ashley PJ (2007) Fish welfare: current issues in aquaculture. Appl Anim Behav Sci 104:199-235. doi:10.1016/j.applanim.2006. 09.001

Bado-Nilles A, Quentel C, Thomas-Guyon H, Le Floch S (2009) Effects of two oils and 16 pure polycyclic aromatic hydrocarbons on plasmatic immune parameters in the European sea bass, Dicentrarchus labrax (Linné). Toxicol In Vitro 23:235-241. doi:10.1016/j.tiv.2008.12.001

Bagni M, Civitareale C, Priori A, Ballerini A, Finoia M, Brambilla G, Marino G (2007) Pre-slaughter crowding stress and killing procedures affecting quality and welfare in sea bass (Dicentrarchus labrax) and sea bream (Sparus aurata). Aquaculture 263:52-60. doi:10.1016/j.aquaculture.2006.07.049 
Basu N, Todgham AE, Ackerman PA, Bibeau MR, Nakano K, Schulte PM, Iwama GK (2002) Heat shock protein genes and their functional significance in fish. Gene 295:173-183. doi:10.1016/S0378-1119(02)00687-X

Beere HM (2004) 'The stress of dying': the role of heat shock proteins in the regulation of apoptosis. J Cell Sci 117:2641-2651. doi: $10.1242 /$ jcs. 01284

Belanger JM, Son JH, Laugero KD, Moberg GP, Doroshov SI, Lankford SE, Cech JJ Jr (2001) Effects of short-term management stress and ACTH injections on plasma cortisol levels in cultured white sturgeon, Acipenser transmontanus. Aquaculture 203:165-176. doi:10.1016/S0044-8486(01)00620-2

Boshra H, Li J, Sunyer JO (2006) Recent advances on the complement system of teleost fish. Fish Shellfish Immunol 20:239-262. doi:10.1016/j.fsi.2005.04.004

Bronzi P, Rosenthal H, Gessner J (2011) Global sturgeon aquaculture production: an overview. J Appl Ichthyol 27:169-175. doi:10.1111/j.1439-0426.2011.01757.x

Conte FS (2004) Stress and the welfare of cultured fish. Appl Anim Behav Sci 86:205-223. doi:10.1016/j.applanim.2004.02.003

Costantini D, Verhulst S (2009) Does high antioxidant capacity indicate low oxidative stress? Funct Ecol 23:506-509. doi:10. $1111 / j .1365-2435.2009 .01546 . x$

Costantini D, Casagrande S, Filippis SD, Brambilla G, Fanfani A, Tagliavini J, Dell'Omo G (2006) Correlates of oxidative stress in wild kestrel nestlings (Falco tinnunculus). J Comp Physiol B 176:329-337. doi:10.1007/s00360-005-0055-6

Costantini D, Rowe M, Butler MW, McGraw KJ (2010) From molecules to living systems: historical and contemporary issues in oxidative stress and antioxidant ecology. Funct Ecol 24:950-959

Currie S, Tufts B (1997) Synthesis of stress protein 70 (Hsp70) in rainbow trout (Oncorhynchus mykiss) red blood cells. J Exp Biol 200:607-614

Deane EE, Woo NYS (2011) Advances and perspectives on the regulation and expression of piscine heat shock proteins. Rev Fish Biol Fish 21:153-185. doi:10.1007/s11160-010-9164-8

Deng DF, Wang C, Lee S, Bai S, Hung SSO (2009) Feeding rates affect heat shock protein levels in liver of larval white sturgeon(Acipenser transmontanus). Aquaculture 287:223-226. doi:10.1016/j.aquaculture.2008.10.041

Di Marco P, Priori A, Finoia MG, Massari A, Mandich A, Marino G (2008) Physiological responses of European sea bass Dicentrarchus labrax to different stocking densities and acute stress challenge. Aquaculture 275:319-328. doi:10.1016/j. aquaculture.2007.12.012

Díaz ME, Furné M, Trenzado CE, García-Gallego M, Domezain A, Sanz A (2010) Antioxidant defences in the first life phases of the sturgeon Acipenser naccarii. Aquaculture 307:123-129. doi:10.1016/j.aquaculture.2010.06.026

Ellis T, Yildiz HY, López-Olmeda J, Spedicato MT, Tort L, Øverli Ø, Martins CIM (2012) Cortisol and finfish welfare. Fish Physiol Biochem 38:163-188. doi:10.1007/s10695-011-9568-y

Eslamloo K, Falahatkar B (2014) Variations of some physiological and immunological parameters in Siberian sturgeon (Acipenser baerii, Brandt, 1869) subjected to an acute stressor. J Appl Anim Welf Sci 17:29-42. doi:10.1080/10888705. 2014.856243

Eslamloo K, Falahatkar B, Yokoyama S (2012) Effects of dietary bovine lactoferrin on growth, physiological performance, iron metabolism and non-specific immune responses of Siberian sturgeon Acipenser baeri. Fish Shellfish Immunol 32:976-985. doi:10.1016/j.fsi.2012.02.007

Falahatkar B, Akhavan SR, Efatpanah I, Meknatkhah B (2012) Primary and secondary responses of juveniles of a teleostean, pikeperch Sander lucioperca, and a chondrostean, Persian sturgeon Acipenser persicus, to handling during transport. North Am J Aquac 74:241-250. doi:10.1080/15222055.2012.675988

FAO (2013) Fishery and aquaculture statistics. FishStat J. In: FAO Fisheries and Aquaculture Department, Rome [online]. Updated 28 Nov 2013. http://www.fao.org/fishery/statistics/software/fishstat/en. Accessed 05 May 2015

Feder ME, Hofmann GE (1999) heat-shock proteins, molecular chaperones, and the stress response: evolutionary and ecological physiology. Annu Rev Physiol 61:243-282. doi:10.1146/annurev.physiol.61.1.243

Feng GP, Zhuang P, Zhang LZ, Duan M, Liu JY (2012) Effects of temperature on oxidative stress biomarkers in juvenile Chinese sturgeon (Acipenser Sinensis) under laboratory conditions. Adv Mater Res 343:497-504

Fontagné S, Bazin D, Brèque J, Vachot $\mathrm{C}$, Bernarde C, Rouault T, Bergot $\mathrm{P}$ (2006) Effects of dietary oxidized lipid and vitamin $\mathrm{A}$ on the early development and antioxidant status of Siberian sturgeon (Acipenser baeri) larvae. Aquaculture 257:400-411. doi:10.1016/j.aquaculture.2006.01.025

Fox J (2005) The R Commander: a basic statistics graphical user interface to R. J Stat Softw 14(9):1-42

Geraylou Z, Souffreau C, Rurangwa E, D'Hondt S, Callewaert L, Courtin CM, Delcour JA, Buyse J, Ollevier F (2012) Effects of arabinoxylan-oligosaccharides (AXOS) on juvenile Siberian sturgeon (Acipenser baerii) performance, immune responses and gastrointestinal microbial community. Fish Shellfish Immunol 33:718-724. doi:10.1016/j.fsi.2012.06.010

Geraylou Z, Souffreau C, Rurangwa E, De Meester L, Courtin CM, Delcour JA, Buyse J, Ollevier F (2013) Effects of dietary arabinoxylan-oligosaccharides (AXOS) and endogenous probiotics on the growth performance, non-specific immunity and gut microbiota of juvenile Siberian sturgeon (Acipenser baerii). Fish Shellfish Immunol 35:766-775. doi:10.1016/j.fsi.2013. 06.014

Ghomi MR, Nazari RM, Poorbagher H, Sohrabnejad M, Jamalzadeh HR, Ovissipour M, Molla AE, Zarei M (2011) Effect of photoperiod on blood parameters of young beluga sturgeon (Huso huso Linnaeus, 1758). Comp Clin Pathol 20:647-651. doi:10.1007/s00580-010-1051-0

Han D, Huang SSY, Wang WF, Deng DF, Hung SSO (2012) Starvation reduces the heat shock protein responses in white sturgeon larvae. Environ Biol Fishes 93:333-342. doi:10.1007/s10641-011-9918-8

Holland MCH, Lambris JD (2002) The complement system in teleosts. Fish Shellfish Immunol 12:399-420. doi:10.1006/fsim. 2001.0408

Huntingford FA, Kadri S (2009) Taking account of fish welfare: lessons from aquaculture. J Fish Biol 75:2862-2867. doi:10.1111/ j.1095-8649.2009.02465.x 
Huntingford F, Kadri S (2014) Defining, assessing and promoting the welfare of farmed fish. Revue Scientifique et Technique (International Office of Epizootics) 33(1):233-44

Kalmar B, Greensmith L (2009) Induction of heat shock proteins for protection against oxidative stress. Adv Drug Deliv Rev 61:310-318. doi:10.1016/j.addr.2009.02.003

Kappenman KM, Fraser WC, Toner M, Dean J, Webb MAH (2009) Effect of temperature on growth, condition, and survival of juvenile shovelnose sturgeon. Trans Am Fish Soc 138:927-937. doi:10.1577/T07-265.1

Keyvanshokooh S, Vaziri B, Gharaei A, Mahboudi F, Esmaili-Sari A, Shahriari-Moghadam M (2009) Proteome modifications of juvenile beluga (Huso huso) brain as an effect of dietary methylmercury. Comp Biochem Physiol Part D Genom Proteom 4:243-248. doi:10.1016/j.cbd.2009.01.002

Khoshbavar-Rostami HA, Soltani M, Hassan HMD (2006) Immune response of great sturgeon (Huso huso) subjected to long-term exposure to sublethal concentration of the organophosphate, diazinon. Aquaculture 256:88-94. doi:10.1016/j.aquaculture. 2006.02.041

Kiron V (2012) Fish immune system and its nutritional modulation for preventive health care. Anim Feed Sci Technol 173:111-133. doi:10.1016/j.anifeedsci.2011.12.015 (Special issue: nutrition and pathology of non-ruminants)

Kolman H (2001) The humoral effects of epin in Siberian Sturgeon (Acipenser baeri Brandt). Arch Pol Fish 9:61-69

Küçükbay FZ, Yazlak H, Karaca I, Sahin N, Tuzcu M, Cakmak MN, Sahin K (2009) The effects of dietary organic or inorganic selenium in rainbow trout (Oncorhynchus mykiss) under crowding conditions. Aquac Nutr 15:569-576. doi:10.1111/j.13652095.2008.00624.x

Lê S, Josse L, Husson F (2008) FactoMineR: an R package for multivariate analysis. J Stat Softw 25:1-18

Linares-Casenave J, Werner I, Van Eenennaam JP, Doroshov SI (2013) Temperature stress induces notochord abnormalities and heat shock proteins expression in larval green sturgeon (Acipenser medirostris Ayres 1854). J Appl Ichthyol 29:958-967. doi:10.1111/jai.12220

Lu X, Rasco BA (2014) Sturgeon (Acipenser transmontanus) sexual maturation and caviar quality. Rev Aquac 6:89-99. doi:10. 1111/raq.12029

Lund SG, Caissie D, Cunjak RA, Vijayan MM, Tufts BL (2002) The effects of environmental heat stress on heat-shock mRNA and protein expression in Miramichi Atlantic salmon (Salmo salar) parr. Can J Fish Aquat Sci 59:1553-1562

Martínez-Porchas M, Martínez-Córdova LR, Ramos-Enriquez R (2009) Cortisol and glucose: reliable indicators of fish stress. Pan Am J Aquat Sci 4:158-178

McEwen BS, Wingfield JC (2003) The concept of allostasis in biology and biomedicine. Horm Behav 43:2-15. doi:10.1016/ S0018-506X(02)00024-7

McEwen BS, Wingfield JC (2010) What is in a name? Integrating homeostasis, allostasis and stress. Horm Behav 57:105-111. doi:10.1016/j.yhbeh.2009.09.011

Monaghan P, Metcalfe NB, Torres R (2009) Oxidative stress as a mediator of life history trade-offs: mechanisms, measurements and interpretation. Ecol Lett 12:75-92. doi:10.1111/j.1461-0248.2008.01258.x

Ni M, Wen H, Li J, Chi M, Ren Y, Son Z, Ding H (2014) Two HSPs gene from juvenile Amur sturgeon (Acipenser schrenckii): cloning, characterization and expression pattern to crowding and hypoxia stress. Fish Physiol Biochem 40:1801-1816. doi:10.1007/s10695-014-9969-9

North BP, Turnbull JF, Ellis T, Porter MJ, Migaud H, Bron J, Bromage NR (2006) The impact of stocking density on the welfare of rainbow trout (Oncorhynchus mykiss). Aquaculture 255:466-479. doi:10.1016/j.aquaculture.2006.01.004

Oliva-Teles A (2012) Nutrition and health of aquaculture fish. J Fish Dis 35:83-108. doi:10.1111/j.1365-2761.2011.01333.x

R Core Team (2014) R: a language and environment for statistical computing. R Foundation for Statistical Computing, Vienna. http://www.R-project.org/. Accessed 10 Jan 2015

Roberts RJ, Agius C, Saliba C, Bossier P, Sung YY (2010) Heat shock proteins (chaperones) in fish and shellfish and their potential role in relation to fish health: a review. J Fish Dis 33:789-801. doi:10.1111/j.1365-2761.2010.01183.x

Sardella BA, Kültz D (2009) Osmo- and ionoregulatory responses of green sturgeon (Acipenser medirostris) to salinity acclimation. J Comp Physiol B 179:383-390. doi:10.1007/s00360-008-0321-5

Saurabh S, Sahoo PK (2008) Lysozyme: an important defence molecule of fish innate immune system. Aquac Res 39:223-239. doi:10.1111/j.1365-2109.2007.01883.x

Schreck CB (2010) Stress and fish reproduction: the roles of allostasis and hormesis. Gen Comp Endocrinol Fish Reprod 165:549-556. doi:10.1016/j.ygcen.2009.07.004

Schreck CB, Contreras-Sanchez W, Fitzpatrick MS (2001) Effects of stress on fish reproduction, gamete quality, and progeny. Aquaculture 197:3-24. doi:10.1016/S0044-8486(01)00580-4

Segner H, Sundh H, Buchmann K, Douxfils J, Sundell KS, Mathieu C, Ruane N, Jutfelt F, Toften H, Vaughan L (2012) Health of farmed fish: its relation to fish welfare and its utility as welfare indicator. Fish Physiol Biochem 38:85-105. doi:10.1007/ s10695-011-9517-9

Silvestre F, Linares-Casenave J, Doroshov SI, Kültz D (2010) A proteomic analysis of green and white sturgeon larvae exposed to heat stress and selenium. Sci Total Environ 408:3176-3188. doi:10.1016/j.scitotenv.2010.04.005

Sørensen JG, Kristensen TN, Loeschcke V (2003) The evolutionary and ecological role of heat shock proteins. Ecol Lett 6:1025-1037. doi:10.1046/j.1461-0248.2003.00528.x

Turnbull J, Bell A, Adams C, Bron J, Huntingford F (2005) Stocking density and welfare of cage farmed Atlantic salmon: application of a multivariate analysis. Aquaculture 243:121-132. doi:10.1016/j.aquaculture.2004.09.022

Wang W, Deng DF, Riu ND, Moniello G, Hung SSO (2013) Heat shock protein 70 (HSP70) responses in tissues of white sturgeon and green sturgeon exposed to different stressors. North Am J Aquac 75:164-169. doi:10.1080/15222055.2012.747457

Werner I, Linares-Casenave J, Eenennaam JPV, Doroshov SI (2007) The effect of temperature stress on development and heatshock protein expression in larval green sturgeon (Acipenser mirostris). Environ Biol Fish 79:191-200. doi:10.1007/s10641006-9070-z 
Whyte SK (2007) The innate immune response of finfish—a review of current knowledge. Fish Shellfish Immunol 23:1127-1151. doi:10.1016/j.fsi.2007.06.005

Williot P (2002) Reproduction des esturgeons. In: Billard R (ed) Esturgeons et caviar. Lavoisier Tech et Doc, Paris, pp 63-90

Williot P, Sabeau L, Gessner J, Arlati G, Bronzi P, Gulyas T, Berni P (2001) Sturgeon farming in Western Europe: recent developments and perspectives. Aquat Living Resour 14(06):367-374

Williot P, Comte S, Le Menn F (2011) Stress indicators throughout the reproduction of farmed Siberian sturgeon Acipenser baerii (Brandt) females. Int Aquat Res 3:31-43

Wuertz S, Lutz I, Gessner J, Loeschau P, Hogans B, Kirschbaum F, Kloas W (2006) The influence of rearing density as environmental stressor on cortisol response of Shortnose sturgeon (Acipenser brevirostrum). J Appl Ichthyol 22:269-273. doi:10.1111/j.1439-0426.2007.00966.x

Xie Z, Niu C, Zhang Z, Bao L (2006) Dietary ascorbic acid may be necessary for enhancing the immune response in Siberian sturgeon (Acipenser baerii), a species capable of ascorbic acid biosynthesis. Comp Biochem Physiol A Mol Integr Physiol 145:152-157. doi:10.1016/j.cbpa.2006.05.015

Zheng K, Wang W, Hung SSO, Deng DF (2015) Feeding rates affect expression of heat-shock protein 70 in green sturgeon fry. North Am J Aquac 77:206-210. doi:10.1080/15222055.2014.987931

Zolfaghari M, Imanpour MR, Najafi E (2011) Effect of photoperiod and feeding frequency on growth and feed utilization of fingerlings Persian sturgeon (Acipenser persicus). Aquac Res 42:1594-1599. doi:10.1111/j.1365-2109.2010.02749.x 